\title{
Judicialization of Politics and the Korean Constitutional Court: the Party Chapter Abolition Case
}

\author{
By Hannes Mosler*
}

\begin{abstract}
In 2004 South Korea's Constitutional Court declared the newly revised Political Parties Act constitutional, whereby it reaffirmed the prohibition of local party organizations by law. Party chapters represent the "party on the ground" and lie at the heart of both the organizational and procedural dimension of the party system. Removing them is thus akin to "emasculating" the political parties and can be understood as a major interference with the realization of democracy. Based on the concept of judicialization of politics this article investigates the decision's juridical rationality and cogency for its formal correctness and actual appropriateness by comparing it with three different authoritative references: the readings of the relevant Korean Constitutional norms as advanced by Korean scholars of Constitutional law, the interpretation of equivalent norms in the German Constitution, and a judgment by the Court itself in a closely related case.
\end{abstract}

\section{A. Introduction}

In 2004, the National Assembly of the Republic of Korea (hereafter: Korea) approved an amendment to the Political Parties Act (PPA) which prohibits the formation of party chapters (chigudang), doing so by a large majority. ${ }^{1}$ Up until then, party chapters had been the basic building blocks of political parties at electoral district level for over forty years. Many of them, however, were infested with corruption, and repeated calls for reform were made aiming to render political parties "less costly and more efficient." The Democratic Labor Party (DLP), a minor progressive party, brought a challenge against the amended Political Parties Act to the Constitutional Court (hereafter: Court), arguing that it infringed upon the freedom to establish political parties and that it violated the imperative of intra-party democracy as laid

* Hannes B. Mosler is assistant professor at the Graduate School of East Asian Studies, Freie Universität Berlin. hannes.mosler@fu-berlin.de. The author would like to express his appreciation to the two anonymous reviewers for their thoughtful comments and invaluable suggestions regarding the submitted draft. He also thanks various other commentators on earlier versions of this paper that he presented at several occasions; he is especially grateful to his colleagues at GEAS, Dr. Brooks Jessup and Dr. Hak-jae Kim, for their generous support. The work on this paper was supported by the Academy of Korean Studies of the Republic of Korea (AKS-2009-MA-1001).

1 Party chapters, regional party organizations below the level of cities and provinces, are also known as "local chapters," "local branches" or "electoral district parties". 
down in the Korean Constitution (hereafter: Constitution). The Court, however, unanimously struck down the challenge to the amended Political Parties Act thus bringing to an end a decade long policy decision process ${ }^{2}$ and a fiercely fought controversy over the question of party chapter reform. In spite of the complexity and inconclusiveness of the issue at hand, the Court's decision turned out to be surprisingly unambiguous. ${ }^{3}$ Korea is a representative democracy and displays the institutional design of a party democracy, i.e. of a system in which political parties play a pivotal role in the process of realizing democratic principles. ${ }^{4}$ Party chapters represent the "party on the ground" 5 and lie at the heart of both the organizational and procedural dimension of the party system. Removing them is thus akin to "emasculating" the political parties ${ }^{6}$ and can be understood as a major interference with the realization of democracy.

Hence, based on the concept of judicialization of politics this article considers the decision as inappropriately intervening into the democratic institutional design and investigates the judicial review with regard to inconsistencies in its reasoning and their causes. The Party Chapter Abolition Case (hereafter: Abolition Case) ${ }^{7}$ has not, so far, been taken into con-

2 See Hannes B. Mosler, Curtailing Political Parties with Efficiency: The Policy Decision to Abolish Party Chapters in South Korea, The German Journal on Contemporary Asia 125 (2012), p. 28.

3 All nine judges fully agreed on the new PPA being perfectly in line with the Constitution. This is remarkable given the fact that the Court is known for the variety of its rulings, ranging from "constitutional" or "unconstitutional" (in whole or part), to "limitedly conforming" (i.e. "constitutional if interpreted in a certain way"), "constitutional but applied in an unconstitutional fashion", and, finally, "nonconforming" (meaning that the respective law has to be amended), Tom Ginsburg, The Constitutional Court and the Judicialization of Korean Politics, in: Andrew Harding et al. (eds.), New Courts in Asia, Routledge 2011, p. 148).

4 For a useful definition of "party democracy," refer to Peter Lösche, Parteienstaat in der Krise: Überlegungen nach 50 Jahren Bundesrepublik Deutschland [The political party state in a state of crisis: Reflecting on the first fifty years of the Federal Republic of Germany], paper presented at a meeting of the Friedrich-Ebert-Stiftung in Bonn on 19 August 1999). The Korean Constitutional Court seems to share this view on the centrality of political parties (Constitutional Court of the Republic of Korea, "Chŏngdangbŏp che-6-cho-ŭi wihŏnsŏng-e taehan kyŏljŏng" [Judgment on the unconstitutionality of Article 6 of the Political Parties Act] in 16 Hŏnbŏpchaep'anso Kyŏljŏngmun [16 Constitutional Court Decision Collection] (2004a), p. 434; Constitutional Court of the Republic of Korea, "Chŏngdangbŏp che-25-cho tŭng-ŭi wihŏnsŏng-e taehan kyŏljŏng (2004-hŏnma-246)", Judgment on the unconstitutionality of Article 25 etc. of the Political Parties Act] in Hŏnbŏpchaep'anso Kyŏljŏngmun [18 Constitutional Court Decision Collection] (2006), p. 411.

5 Richard S. Katz and Peter Mair, Changing Models of Party Organization and Party Democracy: The Emergence of the Cartel Party (1995), 1 Party Politics, p. 15-28.

6 See Richard H. Pildes in a rather similar context, in Richard H. Pildes, The Supreme Court, 2003 Term - Foreword: The Constitutionalization of Democratic Politics, Harvard Law Review 118 (2004), p. 54).

7 Constitutional Court of the Republic of Korea, "Chŏngdangbŏp che-3-cho tŭng-ŭi wihŏnsŏng-e taehan kyŏljŏng (2004-hŏnma-456)" [Judgment on the unconstitutionality of article 3 etc. of the Political Parties Act] (2004) Hŏnbŏpchaep'anso Kyŏljŏngmun [16 Constitutional Court Decision Collection] p. 618-631. 
sideration by the burgeoning literature on the subject of judicialization of politics. ${ }^{8}$ This is surprising, given that this decision was rendered at the same time when an entire series of cases illustrating the judicialization of Korean politics emerged (see below). Scrutinizing this decision with a view to the judges' - overt and covert - deduction therefore promises to be particularly insightful with a view to understanding the genesis of judicialization of politics.

In the remainder of the article I first explain the concept of judicialization of politics and elucidate my methodological approach. Following this, I provide a brief overview on Korea's political (party) system and the DLP - the complainant; give an outline of the Abolition Case and its aftermath, and introduce the Korean Constitutional Court. In the subsequent main part of the article I present the comparative analysis contrasting the Abolition Case's decision with three authoritative references; I finally close with the conclusion on the analysis' findings.

\section{B. Theoretical approach}

Generally the term "judicialization of politics" is used in the literature to describe the phenomenon of increasingly relying on "[the] courts and judicial means for addressing core predicaments, public policy questions, and political controversies." Judicialization of politics

8 See Ji-Bong Lim, Sabŏp-chŏk sokŭkchuŭi-wa sabŏpkwŏn tongnip [Judicial activism and independence of judicial power] (2004) Seoul: Ch’ŏrhak-kwa hyŏnsilsa; Ji-Bong Lim, Politically Sensitive Case and Judicial Activism in Korean Judiciary: Focusing on the Felony Case of Former Presidents Chun \& Roh (2008) Segyepǒphakyeon'gu [13 World Constitution Law Review], p. 247-272; Jong-Cheol Kim, Chŏngch'i-ŭi sabŏphwa-ŭi ŭiŭi-wa han'gye. Nomuhyŏn jŏngbu chŏnban'gi-ŭi sanghwang-ŭl chungsim-ŭro [Constitutional Implications and Limits of the Judicialization of Politics - with reference to judicial activism in the early years of Roh Moo-hyun Government] (2005) Kongbŏbyŏn'gu [33 Public Law Research], p. 229-251; Jong-Hyun Park, The Judicialization of Politics in Korea, (2008) 10 Asian-Pacific Law \& Policy Journal, p. 62-113; Seung-Yong Oh, Minjuhwa ihu chŏngch'i-ŭi sabŏphwa-e kwanhan yŏn'gu [Research on judicialization of politics after democratization] (2009) Kiŏk-kwa Chŏnmang [20 Remembrance and Prospect], p. 282-315; Chaihark Hahm \& Sung Ho Kim, Constitutionalism on Trial in South Korea, (2005) Journal of Democracy, Vol. 16, No. 2, p. 28-42; Chaihark Hahm, Hŏnbŏpchaep'an-ŭi chŏngch'isŏng-e taehayŏ. 'Hŏnbop-chŏk taehwa'modelŭl wihan cheŏn [On the Political Nature of Constiutional Adjudication. A Proposal for a Dialogic Approach to Constitutionalism] (2010) Hŏnbŏphak Yŏn'gu [16 Constitutional Law Research], p. 613-651; Chaihark Hahm, Chŏngch'i-ŭi sabŏphwa-wa hŏnbŏpchaep'an-ŭi chŏngch'ihwa. Segyejŏk bop'yŏnseong-kwa hanguk-chŏk t'ǔksusŏng [Judicialization of politics and politicization of constitutional adjudication. Universal trends and Korean characteristics] (2011) Hŏnbŏphak Yŏn'gu [17 Constitutional Law Research], p. 289-329; Jong-Hyeon Park, Hŏnbŏpchaep'anso-ŭi chŏlyak-chŏk hŏnbŏp tamnon - hŏnbŏpchaep'anso 2008-hŏn'ga-25 (24. September 2009)-wa 2009-hŏnla-8 (29. October 2009) kyŏlchŏng-esŏ-ŭi hŏnbŏp-chŏk nonjŭng-e taehan pip'an [The strategic constitutional discourse of the Constitutional Court. Critical review of the constitutional argumentation of the constitutional decisions 2008-heonga-25 and 2009-heonla-8.] (2010) Pŏp-kwa Sahoe [39 Law and Society], p. 11-40; Un Jong Pak, 'Chŏngch'i-ŭi sabŏphwa'-wa minjujuŭi ['Judicialization of Politics' and Democracy] (2010) Sŏuldaehakkyo pŏphak [51 Seoul National University Law Journal], p. 1-16; Tom Ginsburg, Judicial Review in New Democracies: Constitutional Courts in Asian Cases. Cambridge: Cambridge University Press, 2003; Ginsburg 2011, note 3.

9 Ran Hirschl, The new constitutionalism and the judicialization of politics worldwide, Fordham Law Review 75 (2006), p. 721. 
is an almost inevitable by-product of the ever-growing complexity of modern democratic polities all over the world. ${ }^{10}$ Conceptually the phenomenon can be narrowed down by further distinguishing it from "politicization of the judiciary". On a very basic level politicization of the judiciary depicts instances in which (agents of) the administration or legislature wields influence on the judiciary in a manner or to an extent that transgresses their branch's jurisdiction. Likewise, judicialization of politics is characterized by judges or courts - i.e. their ruling's effect - encroaching on decisions that fall under the jurisdiction of the legislature. ${ }^{11}$ In reality, of course, in many cases both processes are inextricably intertwined and, thus, one can hardly be explained without the other. Yet, conceptually, focusing on one side of the coin is possible and, if applicable, advisable for reasons of analytical accuracy. This is the case in the present investigation that concentrates on an aspect that pertains to the process of judicialization in its narrow sense. The inquiry focuses on the genesis of the judges' reasoning leading to the decision and its determining ramifications for "politics", i.e. institutionalizing parties without ground. ${ }^{12}$

Judicialization of politics as such is neither good nor bad. It can, however, have distorting effects on the democratic system by either leading to specific outcomes that interfere with democratic principles, institutions, and/or practices, or weakening the credibility (and thus the legitimacy) of the institution of the Court in cases where the Court comes to implausible conclusions $^{13}$ - or by doing both at the same time. This is what in the literature has been called

10 Historically, this shift in power away from representational legislatures towards non-elected courts, which thereby transform into powerful bodies of political decision-making, can be traced back to the latter half of the 20th century, when countries other than the traditionally constitutionalist USA transformed into "new constitutionalism states" (Hirschl, 2004), and post-modern polities and politics became increasingly complex. In the early 1990 s, in particular, many countries, including the post-authoritarian Latin American and post-communist eastern European countries, followed by various Asian countries, began experiencing this power shift towards the judiciary as part of a by then global phenomenon. See Thorsten Vallinder, The Global Judicialization of Politics. New York: NYU Press, 1995; John Ferejohn, Judicializing politics, politicizing law, Law and Contemporary Problems 65, (2002) p. 41-68; and Ran Hirschl, The Judicialization of Mega-Politics and the Rise of Political Courts, The Annual Review of Political Science 11 (2008), p. 93-118. See the body of literature at note 8 .

11 Where exactly the boundaries of each branch's authority are depends on a given polity's specificities, however, after all will be almost always subject to interpretation and, hence, probably cannot be identified in absolute terms. Nevertheless, that does not per se render the distinction between the powers irrelevant; on the contrary, it makes even more important to address this precariousness in order not to risk abandoning the fundamental principle of checks and balances in general and, in regard to the countermajoritarian difficulty, in particular.

12 It already sets out with the basic assumption that the judges perceived the super-majoritarian character of the party law - the complainant, who put the controversial matter to constitutional review, was a distinctly minor party - as a substantial pressure on their shoulders.

13 See Jongcheol Kim and Jonghyun Park, Causes and conditions for sustainable judicialization of politics in Korea, in: Björn Dressel (ed.), The Judicialization of Politics in Asia (2012), p. 49, 51. 
the "dark side of the judicialization of politics"14 or "inappropriate constitutional intervention" 15 and what I should like to refer to as judicialization breaking bad. One of its most common manifestations is Courts" "astute strategic behavior [...] adher[ing] closely to prevalent worldviews, national meta-narratives, and the interests of influential elites". ${ }^{16}$ Potentially going hand in hand with judicial behavior is the danger of sabotaging two of the basic duties of constitutional courts: to "address the inherent tension between, on the one hand, the idea of majoritarian democracy, and on the other, the idea of $[\ldots]$ minority or individual rights" 17 , and to secure "background conditions that sustain democracy" by "constraining partisan or incumbent self-entrenchment that inappropriately manipulates the ground rules of democracy." 18

The emergence of the judicialization of politics is prompted by a combination of institutional, structural, and ideational variables. ${ }^{19}$ Institutional variables impacting on the judicialization of politics are the extent of the courts' independence as well as the exact nature of their sovereignty; the relevant structural variables can be found in the opportunity structures resulting from shifts in the power relations among the elites and in state-society relations as a whole; finally, the ideational variables shaping the judicialization of politics comprise the judges' understanding of their role as well as the public perception of judges as authority figures, and, finally, the judges' comportment - attitude and behavior - as reflected in their adjudication. ${ }^{20}$ Thus, how the Court "construct[s] th[e] boundary [between appropriate and inappropriate intervention] will have much to say not just about the logic and structure of constitutional law, but about the experience and practice of democratic politics itself." ${ }^{21}$ It is, by now, a common place that constitutional courts are - necessarily and legitimately - political actors and that "judicial decision-making tends to become politics carried on by other means." 22

However, because of constitutional courts' precarious countermajoritarian character strict criteria are required when it comes to assess whether their decisions were in fact necessary and adequate and do not constitute an excess of jurisdiction: a court's commitment to the text of the constitution, rationality of argumentation, sound interpretation methodology, and in-

14 Kim and Park, note 13, p. 49.

15 Pildes, note 6, p. 154.

16 Ran Hirschl, 'Juristocracy' - Political, not Juridical, The Good Society 13 (2004) p. 10.

17 Hahm and Kim, note 8, p. 29.

18 Pildes, note 6, p. 154.

19 For a discussion of major works on the causes of judicialization, see Björn Dressel, The judicialization of politics in Asia: towards a framework of analysis, in: Björn Dressel (ed.), The Judicialization of Politics in Asia, Routledge, 2012, p. 5; see also Kim and Park, note 13, p. 44.

20 See Dressel, note 19, p. 44

21 Pildes, note 6, p. 154.

22 John Ferejohn, note 10, p. 64. 
dependent judgment. ${ }^{23}$ Drawing on these basic criteria the subsequent analysis of the Abolition Case compares the decision at first with domestic scholarship to assess the entire breadth of the stipulations' potential meaning. The degree to which the principles written in the Constitution are adequately reflected in the Court's interpretation is a vague standard against which to judge, but it is still a crucial one. ${ }^{24}$ Here the constitutional review's soundness is examined in respect to its technical rigorousness and its interpretation's commitment to the provision's text. Of course, the Court is not obliged in any way to be in agreement with mainstream legal scholarship. That would run counter to the basic idea of the Court as an authority of preferably neutral judgment, and would thus render meaningless any distinction between judges and legal scholars. Rather the comparison serves the purpose of investigating how much the Court's interpretation corresponds to the assessment by the majority of domestic constitutional law literature, and where differences originate from. When this has been done, interpretation of legal norms on parties in Germany serve as an authoritative reference for cross-national comparison in line with the generally accepted method of comparative constitutional law as per the fifth canon of statutory interpretation. ${ }^{25}$ Korea's jurisdiction has been heavily influenced by German jurisprudence for over 100 years, ${ }^{26}$ and the country's Constitutional Court is closely modeled on the German Federal Constitutional Court. ${ }^{27}$ Stipulations of the constitution related to political parties can be said to be commendable indigenized versions of their corresponding German models dating back to the $1960 \mathrm{~s} .{ }^{28}$ Again, of course, the Korean Court does not have any obligation to follow, nor is it in any way bound to, interpretation of related legal norms in Germany. Still, in Korea, referring back to German cases is a pervasive custom

23 Christine Landfried, Judicial Policy-Making in Germany: the Federal Constitutional court, West European Politics, 15 (1992), p. 64.

24 For a similar reasoning see Pildes, note 6, p. 154.

25 See Peter Häberle Grundrechtsgeltung und Grundrechtsinterpretation im Verfassungsstaat. Zugleich zur Rechtsvergleichung als "fünfter" Auslegungsmethode, Juristenzeitung (1989), p. 913; see also Axel Tschentscher, Dialektische Rechtsvergleichung - Zur Methode der Komparatistik im öffentlichen Recht [Dialectical Law Comparison - On the method of comparison in Public Law], Juristenzeitung 17 (2007), p. 807-816.

26 See Hyo-Jeon Kim, Hundert Jahre Verfassungsrecht in Korea und Deutschland. Ein Beitrag zur Rezeptionsgeschichte deutschen Rechts in Korea [A hundred years of constitutional law in Korea and Germany. A contribution to the history of reception of German Law in Korea] (1986), in: Peter Häberle (ed.) Jahrbuch des Öffentlichen Rechts der Gegenwart. Neue Folge, Band 35. Tübingen: J.C.B. Mohr Paul Siebeck, p. 577 et seq. Of course, it is well-known that there is also a strong US influence (Hahm, note 8, p. 315).

27 Ginsburg, note 3, p. 148. Jibong Lim, A Comparative Study of the Constitutional Adjudication Systems of the U.S., Germany and Korea, 6 Tulsa. J. Comp. \& Int'l L. 123 (1999), p. 124.

28 The Constitution of 1948 had already been strongly influenced by the Weimar Constitution of Germany (Kim 1986, note 26, p. 587 et seq.), as well as by the Bonner Grundgesetz of 1962 (ibid. 593 et seq.). Korean legal provisions on political parties were "transplanted" from Germany (see SeogYun Song, Togilhŏnbŏp-sang chŏngdangjohang-kwa kŭ han'guk-chŏk isik [The Party Clause of the German Constitution and its Korean Transplantation] (2000) Pöphak [SNU Legal Studies] p. 129 et seq.), as were the rules of legal interpretation and fundamental principles of constitutional review. 
that is justified by the influence of the long history of German jurisprudence on Korean jurisprudence, and by the resulting manifold similarities in legal thought, norms, and legal practice. This makes German law and adjudication to a certain extent the Court's "own standard." Finally, a close precedent - the Party Registration Requirement Case (hereafter: Registration Case $)^{29}$ will be utilized for comparison. Since, both decisions deal with different articles of the PPA, but they touch on the same fundamental question of (intra-party) democracy, the duty of its realization, and the freedom to choose the form of organization as stipulated in Article 8 of the Constitution. Even though the comparison of the two cases might not hold for a doctrinally thorough analysis, it still helps to scrutinize the judges' argumentative reasoning and inference by looking at what possible references the Court did invoke and did not invoke in the two related cases respectively.

\section{Background}

\section{The complainant}

Korea has had a presidential unicameral government system since its foundation in $1948 .{ }^{30}$ Formally, party pluralism has been guaranteed; however, due to division of the Korean peninsula after liberalization from Japanese colonial rule 1945 in Korea only political activities and parties on the right of the ideological divide were allowed. Korea had adopted anti-communism as its official policy. Politicians and parties left from the middle were oppressed and persecuted so that most of them went to North Korea or other countries. The remaining narrow ideological space on the anti-communist right was exclusively shared by reactionary right wing parties of the authoritarian governments on the one hand and liberal parties close to the democratization movement on the other. This has not changed much even after the end of decades of military dictatorship and formal democratization in 1987. The two major parties of today's 298-seat strong parliament ${ }^{31}$, the New Frontier Party (NWP; 156 seats) and the New Politics Alliance for Democracy (NPAD; 130 seats) can be identified as the successor parties of the former and the latter. It was only around the turn to the $21^{\text {st }}$ century that after about half a century Korea saw the formation of its first progressive, left wing party - the Democratic Labor Party (DLP). The predecessor of the DLP had been formed in 1997 under the name of Peoples' Victory 21 as the political arm of the progressive Korean Conference of Trade Unions (KCTU). Three years later the party reorganized into the DLP. Examples of some of the party's main programmatic issues are to represent the rights and interests of workers, farmers and the suppressed people or minjung; to introduce policy measures such as wealth tax, free school meals or increasing the welfare budget; and to abolish the National Security Act and to actively foster relations and exchange with North Korea. At local elections in 2000 the DLP received $8.1 \%$ of the overall votes and won 13 offices; at general elections

29 Court, note 3.

30 The only exception is the Second Republic (1960-1) with a parliamentary and bicameral system.

31 The parliament actually has a total of 300 seats; numbers presented here are as of 6 April 2014. 
in April 2004 the party received 13.1\% and sent in total ten congresspersons to the Assembly. ${ }^{32}$

\section{The Case: Abolition as an "appropriate" means to a "legitimate" end}

In June 2004, three months after party chapters were prohibited by the amended Political Parties Act, the DLP filed a constitutional complaint against the new law. The DLP claimed the new stipulations would violate constitutionally guaranteed rights as stated in Article 8 (Political Parties), Sections 1 and 2 of the Korean Constitution (hereafter: Constitution). Beyond addressing merely the freedom to establish parties (Section 1), the DLP pointed especially to Section 2, where it reads: "The aims, organization, and activities of political parties must be democratic, and they must have the necessary organization to participate in the formation of the political will of the people." ${ }^{33}$ Hence, the DLP argued, eliminating party chapters, which were the bases of the bottom-up democratic organization, would infringe on the guaranteed freedom, would hinder parties organizationally from fulfilling their constitutional duty, and would therefore negatively affect the institution of political parties, a vital device in the representative democratic system. Because party chapters were no longer allowed, political parties were not able to operate their organizations in such a way as to ensure democratic decisions within the party, participative decision making processes, and, finally, participation in the forming of the political will of the people, at least according to the argument of the complainant. $^{34}$

The Court, however, rejected the challenge unanimously. Though it shared the view that Constitution Article 8, Section 1 guarantees the freedom to establish parties. ${ }^{35}$ It even conceded that the forced abolition of party chapters was indeed restricting the freedom of parties guaranteed by the Constitution. ${ }^{36}$ However, the Court concluded that the new law would not violate any "essential aspect of this freedom," 37 even though party chapters are understood to "very effectively carrying out political parties' core function [of participating in the formation of the political will of the people] in a democratic manner." 38 The Court claimed that parties

32 In subsequent elections the party received 5 (2008) and 13 (2012) seats in the National Assembly. Right after the 2012 elections the party split into two; currently the successor parties United Progressive Party (UPP) and Justice Party (JP) account for six and five seats of the Assembly respectively.

33 All translations from Korean into English are mine.

34 Court 2004, note 7, p. 622.

35 Court 2004, note 7, p. 627.

36 Court 2004, note 7, p. 619; Sang-Won Lee, Chŏngdangbŏp che-3-cho-ŭi wihŏnsŏng-e taehan hwagin. Chigudang-ŭi p'yejimunje-ŭi wihŏnsŏng-ŭi munje [Verification of unconstitutionality of Article 3 of the Political Parties Act. The Question of the unconstitutionality of the abolition of party chapters] in Constitutional Court (Ed.) Hŏnbŏpchaep'anso kyŏljŏnghaesŏljip [3 Commentary on decisions of the Constitutional Court of the year 2004] (2005), p. 783.

37 Constitution, Art. 37, Sec. 2.

38 Court 2004, note 7, p. 627; Lee, note 36, p. 788. 
could technically conduct their key functions even without party chapters; it corroborated this assertion by stating that in other countries in which there are no party chapters, and regional organizations are active only at election times, parties can still fulfill their functions; in addition, transportation and telecommunication have developed technologically to such a degree that the importance of regional organizations as conduits for local exchange has diminished. ${ }^{39}$

When verifying whether the new stipulations would infringe upon the principle of proportionality (Verhältnismäßigkeitsprinzip), the Court reasoned that the legislation's purpose would be legitimate, the employed means appropriate as well as necessary, and the infringement minimal. (1) The legitimacy of the aim to improve the parties' low-efficiency, high-cost structure was proven by the fact that this was the main issue raised in the political parties reform debate, and that the existence of this structure would be a major hindrance to a desirable party system..$^{40}(2)$ The employed means of completely abolishing party chapters was appropriate insofar as at least the operating costs of the chapters could be saved, brokerage of illegal funds at the local level could be eliminated, and potential illegal substitute organizations could be controlled by law enforcement agencies. ${ }^{41}$ In addition, the question as to how important party chapters are to party organizations depends on the basic perspective of each party: that is, whether it is a mass-/membership party or a catch-all-/professional election party. ${ }^{42}$ If the former model is adopted, party chapters will be important; in the latter case, party chapters become dispensable. (3) Assessing the necessity of abolishing party chapters, the Court being obliged to assess the least-restrictive among all equally effective options - argued that theoretically there are indeed "milder means" to achieve the pursued aim, but that practically, due to certain circumstances specific to Korea, there are no alternatives to the complete prohibition of any organization on the regional level of election districts. According to the Court, less-infringing measures such as organizational streamlining, operational improvement or financial transparency would not be as efficient as complete abolition, since the phenomenon of high costs and low efficiency for political parties would be inseparably intertwined with party chapters. ${ }^{43}$ (4) According to the Court, the abolition constitutes only a minimal infringement of fundamental rights, because (a) party activities are allowed at the level of provinces and larger cities, (b) organizations for election campaigning may be established temporarily, and (c) transport and telecommunication - "especially the Internet" - permits

39 Court 2004, note 7, p. 627; Lee, note 36, p. 788.

40 Court 2004, note 7, p. 628; Lee, note 36, p. 789.

41 Court 2004, note 7, p. 628; Lee, note 36, p. 790-791.

42 Court 2004, note 7, p. 629; Lee, note 36, p. 795-796.

43 Court 2004, note 7, p. 629; Lee 2005, note 36, p. 807. Also, the Court judged that the proportion between public and private interests was not severely unbalanced because of the amendment, due to political parties' special position and obligations towards the public (Court 2004, note 7, p. 619; Office of the President of the National Assembly (OPNA) 2004-hŏnma-456-e taehan ŭigyŏn. chŏngdangbŏp che-3-cho-ŭi wihŏnsŏng-e taehan p'an'gyŏl [Opinion on 2004-hŏnma-456, judgment on the unconstitutionality of Article 3 of the Political Parties Act], 29 July 2004, p. 4). 
exchange without a real organization on-site. ${ }^{44}$ This assessment of the matter is also shared by Office of the President of the National Assembly (hereafter: OPNA), which supplied its opinion to the Court as part of the proceedings. ${ }^{45}$

By abolishing party chapters for all parties, government and major opposition parties were affected equally, but not fundamentally as minor parties were. As a corollary of the Court's decision on this legal reform, the prohibition of regional party organization by law was confirmed; until today parties are not allowed to install liaison offices. Only a year after the revision - and just a couple of months after the decision by the Court - the Assembly revised the $P P A$ again and, for practical reasons, partly scaled back the ban on local organization, while upholding the prohibition of operating offices. In fact, however, almost all parties, depending on their capabilities, continued to operate organizations at local level unofficially and illegally. In this way minor parties had a disproportional disadvantage, because they cannot fall back on alternative office space as in the case of incumbent members of major parties. The Political Funds Act (Article 9) allows only incumbent members of the Assembly or candidates to operate liaison offices in their respective election districts to administer their supporters' associations, which they covertly use for their party's local organization. This makes minor parties with only a handful of congresspersons particularly dependent on legally granted organization at lower administrational levels. In this context it is important to note that also scholarly research ${ }^{46}$ and news reports ${ }^{47}$ reveal that following the abolition of party chapters

44 Court 2004, note 7, p. 630; Lee 2005, note 36, p. 797.

45 OPNA 2004, note 43, p. 4.

46 See Jeong-jin Lee, Chigudang p'yeji-ihu chiyŏk-esŏ-ǔi chŏngdanghwaldong [Regional activities after the abolition of party chapters] (2008) 1 Kukhoeipbŏpchosach'ŏbo [National Assembly Research Service Review] 62-67, p. 66; Jinyoung Jeon, Chigudang p'yeji-ǔi munjejŏm-kwa puhwal-ǔl tullŏsan chaengjŏm kŏmt'o [Review of the abolition of local party branches] (2009) 2 Hyŏndaejŏngch 'iyŏn'gu 2 [Contemporary Korean Politics Research] 173-196, p. 188 et seq. Jeongjin Lee, Chigudang pyeji-rŭl tullŏssan tamnongujo-wa bŏp kaejŏng nonjaeng [Discourse structure and legal reforms in regard to the abolition of party chapters]" (2010) 31 Han'gukjŏngch'iwoegyosanonch'ong 2 [31 Korea Diplomatic History Review 2] p. 353-384; Jongbin Yoon, Chigudang pyeji-wa han'gukjŏngdang-ŭi minjusŏng [The abolition of local party organization and intra-party democracy in Korea] (2011) 10 Han'gukjŏngdanghakhoebo 2, 19 [10 Korea Party Studies Review 2, 19], p. 67-92; Man-hee Jeong, Chŏngdangbŏp-sang chŏngdang-ŭi chayujehan-ŭi munjejŏm [The problems of the Political Parties Act restricting the freedom of parties] (2012) 54 Tongabŏphak [54 Dong-A Law] 107-147, p. 130 et seq.; Dong-Yoon Lee, Han'guk chŏngdang-ŭi hubogongch'ŏn-kwa taep'yosŏng: che-19-tae kukhoeǔiwŏnsŏn'gŏ-rŭl chungsim-ŭro [Candidate nomination and representation of political parties in Korea: with focus on the 19th National Assembly election] (2012) Chŏngch'ichŏngboyŏngu che-15-kwŏn 1-ho [15 Politics \& Information Research 1] p. 93-129, at 117; Jongbin Yoon, Han'guk chŏngdangyŏn'gu-ŭi iron-chŏk pangbǒmnon-chŏk tae'an-ŭi mosaek [In search for a theoretical and methodological alternative of Korean political party research] (2013) 3 Miraechŏngch'iyŏn'gu 1 [3 Journal of Future Politics 1] p., 5-18, at p. 15f. The literature is divided on whether the abolition was useful or not and on how to organize parties on a local level, but seems to agree on the need for local party organization as such.

47 Only recently, in the context of the so-called "money envelope-scandal," the press has once again denounced the still thriving corruption within political parties and has emphasized the fact that 
little has changed with regard to intra-party malpractice. Moreover many scholars, politicians as well as party members from almost all parties keep stressing the need for being allowed to operating party chapters at a local level.

\section{The Court: between democratization and judicialization}

That it was the Korean Constitutional Court that rendered a decision with these consequences seems at first surprising for the following reasons: First of all, the Court is counted among the most reliable and successful Constitutional Courts in Asia, and justifiably so. ${ }^{48}$ From the very moment of its establishment in the late 1980s, right through the 1990s, it has played a crucial role in the development of the Korean polity, contributing to the consolidation of democra$\mathrm{cy}^{49}$ by, among other things, actively promoting freedom of expression, ${ }^{50}$ bolstering institutions of representative democracy, ${ }^{51}$ and emphasizing the rights and freedoms of political parties as prerequisites for the realization of democracy. ${ }^{52}$ There are numerous other examples

corruption practices have not changed following the abolition of party chapters in the year 2004 (Munhwa Ilbo, 10 January 2012: p. 4). In addition, the ruling party, the main opposition party, and even the National Election Commission have recently begun to consider plans to re-introduce party chapters (Choson Ilbo, 16 April, 2013: A5). Reports on how former party chapters are still being operated - now illegally - with the same effects are easily be found (see for example editorial of the daily Choongang Ilbo, 2 February 2014). On top of this, the recent case of Member of Parliament Jae-kwon Shim, who is accused of illegally operating a party chapter office, prompted the Seoul Eastern District Court to request a ruling by the Constitutional Court on article 37-3 (Freedom of Activities) of the PPA (Tonga Ilbo, 26 June, 2013: 12).

48 Ginsburg 2003, note 8; Ginsburg 2011 note 3.

49 Ginsburg 2011, note 3, p. 155; Kim \& Park 2012, note 13, p. 39; Dressel 2012 note 19, p. 1.

50 Ginsburg 2003, note 8, p. 207.

51 Decisions such as those on the (in-)equality of opportunities as between independent and partyaffiliated candidates in 1989 (89-hŏn'ga-6) and 1992 (92-hŏnma-37), as well as those on guaranteeing proportional representation not only in rural as well as urban areas (in 1996, 95-hŏnma-224) but also for minority candidates (Ginsburg 2011 note 7, p. 150). The Court's decision on The Public Election Law (PEL) in 2001 (2000-hŭnma-91.112.134; consolidated) is the most remarkable case in this respect, since it rendered the existing voting law unconstitutional leading to a law reform in 2002 that introduced next to the vote for the election district representative a second vote exclusively for the supported party (Zweitstimme; PEL 2002).

52 The following count among the most exemplary decisions: Decision of 23 December 1999, 1999hŏnma-135 [Korean Constitutional Court]; Constitutional Court of the Republic of Korea, Gyŏngch'albŏp che-11-cho che-4-jang tŭng wihŏnhwagin. 99-hŏnma-135 [Judgment on Article 11, Section 4 of the Police Law. Hŏnje 1999.12.23, P'allyejib che-11-gwon 2-jib [11 Constitutional Court Decision Collection] 800-822, p. 815; Constitutional Court of the Republic of Korea, Chŏngdangbŏp che-6-cho-ŭi wihŏnsŏng-e taehan kyŏljŏng [Judgment on the unconstitutionality of Article 6 of the Political Parties Act] (2004) in Hŏnbŏpchaep'anso Kyŏljŏngmun [16 Constitutional Court Decision Collection] p. 422-440, 434; to a lesser degree this is also true for: Constitutional Court of the Republic of Korea, Chŏngdangbŏp che-25-cho tŭng-ŭi wihŏnsŏng-e taehan kyŏljŏng [Judgment on the unconstitutionality of Article 25 etc. of the Political Parties Act] (2006) in Hŏnbŏpchaep'anso Kyŏljŏngmun [18 Constitutional Court Decision Collection] p. 402-416, at p. $402 f$. 
of Constitutional adjudication that can be considered successful with a view to social and economic policy-making. ${ }^{53}$ It was only in the years following the year 2003 that consecutive instances of judicialization of politics of a new quality began to occur, including the following landmark cases: ${ }^{54}$ the Presidential Referendum Case (Nov. 2003), ${ }^{55}$ the Impeachment of President Roh Moo-hyun Case (May 2004), ${ }^{56}$ the Relocation of the Capital City Case (Oct. 2004), ${ }^{57}$ and the Administrative Center Multi-City Case (Nov. 2005). ${ }^{58}$ Intra-elite and statesociety dynamics occurring after the first democratic turn-over (Huntington) in 1998 and during the ensuing period of the two consecutive liberal-progressive governments under President Kim Dae-jung (1998-2003) and President Roh Moo-hyun (2003-2008) respectively have to be considered as providing an important contextual setting for the landmark cases cited above.$^{59}$ Since, subsequently, the permeability of the political arena leads to a double cleavage structure of power-relations: between former and new power holder, on the one hand, and between entrenched (major) and aspiring (minor) forces, on the other. A new generation of politicians started to enter politics and became the driving force behind political reforms opening up and pluralizing the arena of institutionalized politics. The introduction of the proportional representation election system is one of the most representative reforms of this time, and was crucial for the minor DLP to enter parliament in 2004 and to constitutionally challenge the entrenched forces. In the course of the struggle for hegemony between the old and the new power-holders the Court developed into one of the main venues of this conflict.

This complex opportunity structure depicts the context, in which the Abolition Case has to be understood. What distinguishes the decision from the other landmark cases in Korea is that the reform to abolish party chapters was jointly decided on by the ruling party and the main opposition parties. From the Court's perspective ruling against a decision that was agreed upon by the wide majority of lawmakers from both sides of the government-opposition divide

53 The House Head System Case and the Comprehensive Real Estate Tax Case count among the representative examples. For more detailed information, see Kim and Park 2012 note 13, at p. 40; see also Ginsburg 2011, note 3, p. 166-168.

54 For a brief overview of the cases see Hahm and Kim 2005, note 8, p. 35-39; also see Kim and Park 2012, note 13 , p. 40-44.

55 15-2(B) Korean Constitutional Court Report 350, 2003-hŏnma-694, etc. (consolidated), 27 November 2003 .

56 16-1 Korean Constitutional Court Report 609, 2004-hŏnna-1, 14 May 2004.

57 16-2(B) Korean Constitutional Court Report 1, 2004-hŏnma-554, 566 (consolidated), 21 October 2004.

58 17-2 Korean Constitutional Court Report 481, 2005-hŏnma-579, 763 (consolidated), 24 November 2005.

59 Kim and Park 2012, note 11, p. 45. 
meant a high risk losing future bargaining power, i.e. political capital towards other constitutional institutions such as the legislature and administration. ${ }^{60}$

\section{Analysis}

\section{Judging by domestic scholarship}

Most of the best-known Korean scholars of constitutional law have criticized the abolition as running counter to the principles of democracy as prescribed by the Constitution, or at least as being very controversial. ${ }^{61}$ Some have even said that they would have made completely the opposite decision from that made by the Court. ${ }^{62}$ What are the contentions domestic scholars raise against the Court's decision?

First of all, the legitimacy of the amended stipulations' aim of "high efficiency and lowcost politics" is not as obvious as the Court portrays it. To begin with, the economic concept of cost and profit (i.e. efficiency) seems "ill-suited" as an issue within the political domain, since in its function "to organize participation, to aggregate interests, [and] to serve as the link between social forces and the government $[\ldots]$ the party necessarily reflects the logic of po-

60 Granting the claims of the constitutional challenge to the abolition would have had the risk of being mistaken by the public as anti-reformist or even reactionary. On "public preferences" in Korea, see Jongcheol Kim, Government reform, judicialization, the development of public law in the Republic of Korea, in Tom Ginsburg and A. Chen (eds.), Administrative Law and Governance in Asia: Comparative Perspectives, London, UK: Routledge, p. 103, 116.

61 Young-Soo Chang. On the unconstitutionality of the party chapter abolition and the legality of the constitutional appeal about the infringement of fundamental rights as result of it, (2005) Goshi Yeŏn'gu Vol. 381/12, p. 31; see Young-Soo Chang, Chigudang p'yeji-wa wihŏnsŏng-kwa kŭ-ro inhan kibon'gwŏn ch'imhae-e taehan hŏnbŏpsowŏn-ŭi chŏkpŏpsŏng [On the unconstitutionality of the party chapter abolition and the legality of the constitutional appeal about the infringement of fundamental rights resulting from it] (2005) Kongbŏbyŏn'gu [381 Public Law Research], p. 25-37, at p. 31; Swoo-Woong Han, Chŏngdang-ŭi kaenyŏm-kwa chŏngdang tŭngnok-ŭi hŏnbŏp-chŏk munjejŏm. Hŏnjae 2006. 3. 30. 2004hŏnma246 kyŏljŏng-e taehan p'alyep'yŏngsŏg-ŭl chungsim-ŭro [The constitutional notion of political parties and problems of party registration in constitutional law. Focusing on the review of the constitutional court's decision 2004hŏnma246 from 30. March 2006] (2008) Chŏsŭt'isŭ [104 Justice] p. 5-23; Swoo-Woong Han, Hŏnbŏp che-8-cho chŏngdangjohang-ŭi kyubŏm-chŏk ŭimi [The normative meaning of the provisions upon political parties of the Korean Constitution Article 8] (2008a) Chungangbŏphak [10 Chung-Ang Law Review] p. 9-61; Song 2007, note 19; Tae-Ho Jeong, Chŏngdang haesansimp'an-ŭi siljŏk yogŏn [Concrete preconditions of ruling political parties' dissolution], in: The Constitutional Court (Ed.), Chŏngdangaesanjedo-e taehan yŏn'gu [On the system of ruling on the dissolution of political parties] (2004) p. 92-125; Nak-In Seong, Hŏnbŏphak. [Constitutional Studies] Seoul: Beommunsa, 2006; Hee-Yol Kay, Hŏnbŏphak. Sang [Constitutional Science. Volume I.] Seoul: Pagyŏng Publishing, 2005; Tae-Ho Jeong, Chigudang-ŭi kangje-jŏk pyeji-ŭi wihŏnsŏng. Hŏnje 2004.12.16 2004-hŏnma-456 [On the unconstitutionality of the forced abolition of party chapters. Critical review on the Constitutional Court's decision 2004-hŏnma-456] (2006), in: Hŏnbŏpsilmuyŏn'guhoe [Constitutional Case Research Association] (Ed.) Hŏnbŏpsilmuyŏn'gu [7 Constitutional Case Research], p. 203-261.

62 Jeong 2006, note 61; see also Mosler 2011, note 2, p. 255. 
litics, not the logic of efficiency." ${ }^{63}$ Moreover, improving democracy by cutting costs can be said not only to be an argument turned on its head, ${ }^{64}$ but above all to be a "very precarious experiment" 65 of "manipulating the very design of democratic institutions." $"$ Likewise, it is doubtful whether this legal reform was in accordance to public interest and whether the majority of the Korean people were in favor of abolition (instead of reform) of the party chapters. ${ }^{67}$

Second, whether lawmakers actually intended to eliminate party chapters completely is put into question. While the statement of the Office of the President of the National Assembly mistakenly conveys the impression this was the case ${ }^{68}$, statements of key actors, i.e. direct decision-makers on the parliamentary sub-committee tell a different story. ${ }^{69}$ Asked in an interview after the amendment why they (i.e. lawmakers) would have pled for the abolition, one lawmaker replied that he had thought only the legal obligation to have party chapters would be abolished and not the freedom to have them if desired. Another assemblyman gave a similar answer, saying that he did not think of completely forbidding party chapters, but would have envisaged regional organizations such as those existing in the US, where party chapters are active only around election times. ${ }^{70}$ Indeed, just a year later, the Assembly decided on an additional reform to the $P P A$ that once again allowed basic organization of political forces on the ground in order to "extend political parties' autonomy" and to "improve on partial deficits

63 Samuel Huntington, Political Order in Changing Societies. (1968) [The Henry L. Stimson Lectures Series] New Haven: Yale University Press, p. 92.

64 Myung Koo Kang and Sang-Hun Park, Chŏngch'i-chŏk sangjing-kwa tamnon-ŭi chŏngch'i. 'sinhan'guk-esŏ 'segyehwa'-kkaji' [Political symbols and discursive politics. From 'New Korea' to 'Globalization'] (1997) Han'guksahoehak [31 Korea Social Science], p. 123-161; Dae-Hwa Jung, Chŏngch'ibŏpchedo kaesŏn-ŭl wihan taet'oronhoe [Workshop on improving political laws and system], KCTU, 23 July 1998.

65 Mun-Hyŏn Kim, Chu-Hwan Kim and Ji-Bong Lim, Kibon'gwon yŏngyŏk-pyŏl wihŏnsimsa-ŭi kijunkwa pangbŏp [Criteria and methods for unconstitutionality review in different domains] (2008), Sŏul: Hŏnbŏpjaep'anso, p. 378.

66 See Pildes, note 6, p. 48.

67 Only two exceptional opinion polls during the ten years before the abolition turned out to be in slight favor of an abolition (Hannes B. Mosler, Sarajin chigudang, kongjŏn-hanŭn chŏngdang kaehyŏk [Party chapters disappeared, party reforms idling]. Koyang: In'gansarang, 2013, p. 381.).

68 OPNA 2004, note 43.

69 Sub-Committee on Political Reforms, Che-244-hoe kukhoe (imsihoe.kaehoejung) Chŏngch 'igaehyŏk wiwŏnhoe hoeŭirok Chŏngdang Sowiwŏnhoe Che-2-ho [244th Session of the Assembly Records of the Special Committee on Political Reforms' Sub-Committee on the Political Parties Act] (2004), 27 January 2004, p. 1-10.

70 Hannes B. Mosler, Tamnonbunsŏk-chŏk chŏpkŭn-ŭro koch'arhae pon chedogaehyŏk-ŭi chŏngch'aek kyŏljŏng kwajŏng-e taehan yŏn'gu. Han'guk chigudang p'yeji sarye-rŭl chungsim-ŭro [Discourse analytic approach to the study of institutional reform's policy process: The case of South Korean political party chapters' abolition], PhD diss., Seoul National University, 2011, p. 222 et seq. 
of the current system." ${ }^{71}$ In other words, the Assembly did in fact decide for the abolition, but it had not been its original intention to do so. ${ }^{72}$ And even though it is not the duty of the Court to compensate for mistakes made by the Assembly, in other cases - for example, in the decisions on the passing of the "media laws," social network services during election campaigning ${ }^{75}$ to name only a few — the Court explicitly signaled ${ }^{76}$ the need for the Assembly to do its work properly.

Third, the Court, in seeking to prove the means' appropriateness, claims that abolishing party chapters will, at the very least, offer savings to parties on operating costs, and help prevent illegal activities that could lead to even higher costs. But this does hardly attest to why this should be considered a reasonable justification for the measure. For example, one counter-proposal to the abolition was to strengthen party chapters' autonomy vis-à-vis the central party in order to solve or at least to mitigate causes of corruption and thus high costs. However, this alternative has not been considered an option by the Court. So, by reasoning that other possible measures would not be an option the Court deprived itself of a balanced consideration from the outset. The same applies for the Court's assertion that "in Korea there is no other way apart from abolition", which reveals a fatalistic reasoning rather than a wellbalanced and substantiated one. For one thing, it is an obvious contradiction to state that "the institution of party chapters as such was not the problem," 77 but at the same time to justify the abolition of party chapters by asserting that there was no other way of solving the problem. Another contradiction in reasoning can be found in the Court's earlier line of argumentation, in which it stated that any possible illegal activities could be suppressed by enforcement of applicable laws. If illegal activities can be prevented simply through law enforcement, there obviously are milder means by which to prevent fraud and undemocratic behavior - for example, legal stipulations determining how to run party chapters democratically.

Fourth, the Court stated that it would not judge the desirability of the measure to abolish party chapters. ${ }^{78}$ Here the Court is obviously referring to the principle of legislative discretion or functional correctness, according to which constitutional courts, by definition, do not make

71 Political Parties Bill (PPB) 2005. While organization as such was allowed again, establishing and operating office space for the purpose of meetings remained prohibited (PPA 2005, Article 37, Paragraph 3). Persons violating this stipulation can be sentenced to up to two years of imprisonment or a fine of up to two million Korean Won (PPA 2005, Article 59).

72 Of course, this does not mean that the Court is obliged to compensate for the Assembly's error, but it does mean that the amendment can hardly be said to reflect lawmakers' intentions.

73 Decision of 29 October 2009, 2009-hŏnla-8 [Korean Constitutional Court].

74 Decision of 24 September 2009, 2008-hŏn'ga-25 [Korean Constitutional Court].

75 Decision of 29 December 2011, 2007-hŏnma-1001 [Korean Constitutional Court].

76 On "signaling" see James R. Rogers, Information and Judicial Review: A Signaling Game of Legislative-Judicial Interaction, American Journal of Political Science, Vol. 45, No. 1 January 2001, p. 84-99.

77 Court 2004, note 7, p.628; OPNA 2004, note 43, p. 2.

78 Court 2004, note 7, p. 629. 
qualitative pronouncements on the contents of a law, but judge its implications solely on the basis of a Constitution's statutes. ${ }^{79}$ In fact, however, the Court did indeed evaluate the PPA's amended article with respect to its effectiveness in accomplishing the aim that the legislature had "intended." It can even be said that the Court judged the appropriateness of the abolition from a biased position that favored a certain conception, i.e. the professional-election, catchall party-model. ${ }^{80}$

Fifth, the Court's contention of minimal infringement because of the possibility of party activity at the regional level, election campaigning, and developments in transport and telecommunications infrastructure seems, on the surface, to be convincing — at least inasmuch as it asserts that the significance of party chapters has decreased due to a change in the overall empirical environment. However, in considering a more fundamental question, the main critique from constitutional scholars concerning the decision focuses on the question of democracy, especially intra-party democracy and the required organizational characteristics thereof. In order to fulfill its task of participating in the formation of the political will of the people and as a crucial part of realizing the overall process of democracy for the whole polity, a certain spatial diffusion of party organization is mandatory. ${ }^{81}$ That is, to ensure an effective political process within the party, i.e. for as many citizens as possible to participate in the process of formation of political will, the party organization has to be in appropriate proximity to the people. ${ }^{82}$ This perception of parties and their regional organizations goes back to an understanding of parties as "more than mere instruments for election mobilization." 83 In the same vein, a number of renowned scholars of constitutional law confirm in their annually updated commentaries that Article 8, Section 2 of the Constitution also encompasses the need for party organizations to be of "permanence" and "solidness." 84 For, in order to fulfill the duties as prescribed in the Constitution (Art. 8, Sec. 2) and the PPA (Art. 2), party organizations have to be, to a certain degree, lasting and must guarantee a certain regional proximity

79 Konrad Hesse, Grundzüge des Verfassungsrechts der Bundesrepublik Deutschland [Essentials of constitutional law of the Federal Republic of Germany]. Neudruck der 20. Auflage. Heidelberg: C.F. Müller, 1999, p. 28 et seq. Hee-Yol Kay (Ed.), Hŏnbŏp-ŭi haesŏk [Interpretation of the Constitution], Seoul: Korea University Publishing, 1993, p. 75 et seq.

80 Jeong, note 61, p. 238.

81 Jeong, note 61, p. 229 et seq.

82 See Chang, note 61, p. 30; Kwon (2002) in a thorough study on party organization goes even a step further, arguing that inner-party democracy can only be realized if party chapters are further subdivided, in: Young Ho Kwon, Togil Chŏngdang-ŭi naebujilsŏ-e kwanhan yŏn'gu [A Study on the Internal System of Political Parties in Germany] (2002) T'oji kongbŏbyŏn'gu [16 Public Land Law Research], p. 122).

83 Jeong, note 61, p. 206.

84 See Yeong Huh, Han'gukhŏnbŏmnon [Theory of the Korean Constitution] Seoul: Pagyŏng Publishing, 2002 at p. 235; Cheol-Su Kim, Hŏnbŏphak kaeron [Introduction to Constitutional Science]. Seoul: Pagyŏngsa, 2005 at p. 190; Lee, note 36, p. 774; Kay, note 67, p. 261; Seon-Yeong Kwon, Hŏnbŏphak wŏllon [Principles of Constitutional Science]. Seoul: Pŏmmunsa, 2004, p. 193). 
within the reach of the people. ${ }^{85}$ This casts doubt on the contention that the "management of members via the Internet" and other media, as well as temporal mobilization during election campaigning, would suffice to fulfill the party stipulations in the Constitution. ${ }^{86}$

Against this background, Kay assesses the abolition of party chapters as "not only contrasting [with] principles of [intra-] party democracy, but also greatly running counter to democratization." According to him, the abolition was an "undemocratic amendment that cannot be justified by any reason." ${ }^{87}$ Jeong maintains that party chapters and other regional forms of organization should be allowed in order to ensure participation in the democratic formation of the political will as stipulated in the Constitution. ${ }^{88}$ Han criticizes the abolition insofar as it would "hinder the parties from fulfilling their constitutional obligation, which, thus, imposes an immoderate restriction on the freedom of political parties." 89 All in all, the decision to prohibit party chapters can hardly escape the criticism of having violated the review practice principle against excessive restriction ${ }^{90}$ or Übermaßverbot. ${ }^{91}$

\section{Judging by authoritative reference from Germany}

The following paragraphs turn to German legal norms regarding regional party organization that often is drawn on or invoked by Korean legal scholars and practitioners as authoritative reference. By scrutinizing pre-enactment documentation of the German Political Parties Act (hereafter: PartG), I seek to identify the initial idea behind the norms and, by implication, obtain insights for a possible interpretation of the provisions on political parties in the Korean Constitution.

Between 1955 and 1957, a commission of the German Ministry of the Interior (hereafter: Commission) that was in charge of preparing stipulations for party law held meetings on the interpretation of Article 21 of the German Basic Law (hereafter: GG). In a fundamental and very thorough review, a group of constitutional scholars inquired about definite provisions that would have to be implemented according to GG, Article 21, Section 3 ("Details shall be regulated by federal laws.”). It finally produced a report in 1958 that served as the basis for

85 Jeong, note 61, p. 231; Kay, note 61, p. 261.

86 See Court 2004, note 19, p. 627; OPNA 2004, note 43, p. 3; Lee, note 36, p. 797.

87 Kay, note 61, p. 274, note 169a; similar see Jeong, note 61, p. 120, note 208.

88 Man-Heui Jeong, Hŏnbŏp che-8-cho - chŏngdang [Article 8 of the Constitution - Political Parties] in Korean Association of Constitutional Studies (Ed.), Chusŏksŏ I [Commentary on the Constitution I] Seoul: KACS, 2007, p. 162 et seq.

89 Han, note 61, p. 34 et seq., supranote 71. Also, the counter-criticism of questioning whether party chapter organizations were the only way of guaranteeing the realization of (intra-party) democracy (Il-Seon Hong, Chigudang-ŭi kangjejŏk p'yeji-ŭi 'wihŏnsŏng'-e taehayŏ [On the 'unconstitutionality' of the forced abolition of party chapters] (2006) Hŏnbŏpsilmuyŏn'gu [7 Constitutional Case Research] p. 262-266, at p. 265) only leads back to the basic question of "how much" freedom of democracy is enough for the law to be constitutional.

90 Constitutional Court of Korea, The First Ten Years of the Korean Constitutional Court, 2001, p. 125.

91 See Kim et al. 2008, note 65, p. 378. 
the enactment of the PartG in 1967 and, even before that, in 1962, in a number of crucial parts, for that of the Korean PPA as well as for the provisions on parties of the Korean Constitution. This is most explicitly reflected in the stipulation that "parties must have the necessary organization to participate in the formation of the political will of the people" (Korean Constitution, Article 8, Paragraph 2; PPA, Article 1). Since, this obviously draws on PartG, Article 7 (Paragraph 1, Sentence 3) and GG, Article 21 (Paragraph 1, Sentence 1).

The Commission's report provides further assessments that are relevant for understanding the constitutional norms on parties in regard to the question of party organization on the ground. First, the Commission identified the "continuity and persistence" of the party organization as a crucial aspect to be stipulated in the PartG, according to the order of the GG Basic Law. The features of continuity and persistence of the organization are directly related to parties' obligation to "participate in the formation of the political will of the people" as stipulated in GG Article 21, Section 1, Sentence 1. ${ }^{92}$ It is these very features that the Korean Court bypassed when reviewing the case. It was the opinion of the Court, as well as the OPNA, that the Public Election Law would provide the necessary stipulations for regional organizations to mobilize at election times, as a compensation for the forbidden party chapters. ${ }^{93}$ However, if the Court had referred to these concepts of continuity and persistence as they are explicated in their German counterpart as reference, as well as the idea behind the concepts, the contradiction in the review's argumentation would have become obvious at once. Whether this was the reason for the Court not exploiting this obvious reference, which is used frequently in Korean jurisdiction, is unknown, but it points to a clear gap within the Court's opinion when compared to alternative interpretations.

Second, besides continuity and persistence, party organization must be of "sufficient size and strength." ${ }^{94}$ Speaking in more concrete terms, parties have to have a "regional structure [...] developed to a sufficient degree." ${ }^{, 5}$ Here, the notion of sufficiency is based on the idea that individual party members actually have to be able to participate in the process of formation of the political will of the party ${ }^{96}$ in order to guarantee constitutionally regulated inner-party democracy. ${ }^{97}$ Provisions of Article 8, Section 2 of the Korean Constitution imply, too, the obligation of a bottom-up decision structure within parties that "grants the members the possibility of being able to participate in [...] the formation of the will." 98 But it remains mute

92 Kommission des Innenministeriums [Commission of the Ministry of the Interior]. Rechtliche Ordnung des Parteiwesens. Probleme eines Parteiengesetzes. Bericht der vom Bundesminister des Innern eingesetzten Parteienrechtskommission [Legal regulation of the party system. Report of the party law Commission appointed by the Minister of the Interior] (Frankfurt/Main: Alfred Metzner Verlag, 1958), p. 126 et seq.; see also BVerfGE 24, 260 (263f.) (1968).

93 Court 2004, note 7, p. 630; OPNA 2004, note 43 p. 2 et seq.

94 PartG, Article 2, Section 1; BVerfGE 91, 276 (284; 288; 290) (1994); BVerfGE 91, 262 (270) (1994).

95 PartG, Article 7 Section 1; BVerfGE 91, 276 (289; 291) (1994); BVerfGE 91, 262 (271) (1994).

96 PartG Article 7, Section 1, Clause 3; BVerfGE 91, 262 (271) (1994).

97 GG Article 21, Section 1, Clause 3.

98 Jeong, note 88 , p. 157 ; similar ibid. p. 159 and p. 162 et seq. 
about more concrete terms, which belong to the task of constitutional interpretation. If we follow the German interpretation, a regionally subdivided organizational structure of political parties becomes an inevitable condition for ensuring equal opportunities for individual members' participation. ${ }^{99}$ More precisely, the minimum necessary extended organization has to feature a vertically multileveled structure of territorial units within a particular area; that is, it has to be subdivided into regions and communes. ${ }^{100}$ Ipsen (2008), for example, pleads for a formula that sets the size and number of members in relation to the degree of structural extension: the more members a party has, the higher the degree of regional subdivision should be. ${ }^{101}$ Only then could the stipulated need for "endurance" and "solidness" within the organization be guaranteed, ${ }^{102}$ and only then can it fulfill its constitutional functions. ${ }^{103}$ Put differently, the measure according to which regional organization is structured vertically is the effective participation of individual members in the process of formation of the political will. ${ }^{104}$ As a corollary, the vital significance of inner-party democracy that the German interpretation infers is that "abolition or cutoff of an active and determining influence by the party members [and] the formation of the will 'from above' or 'from outside' [...] is contrary to the [...] Basic Law." 105 The Korean Constitutional Court came to very similar conclusions in earlier reviews, when it explicitly acknowledged that "party chapters are not simply suborganizations of the central party, but to a certain degree autonomous organizations [...]," ${ }^{106}$ and, in reference to the Constitution, Article 21, Section 2 (freedom of assembly), established that the reason for political parties' special protection by the constitution in com-

99 See Jörn Ipsen, Parteiengesetz (ParteienG): Gesetz über die politischen Parteien. Kommentar [Party Law (ParteienG): Law on Political Parties], 2008. München: C.H. Beck p. 64; Martin Morlok, Artikel 21 [Article 21] (2006) in Grundgesetz-Kommentar, Bd. 2,2, edited by Horst Dreier. Tübingen, p. 327-403, at p. 384. This kind of complex party organization in turn leads to the need for a minimum level of membership, which, however, would not necessarily be determined by a concrete number (Commission 1958, note 39, p. 134).

100 Commission 1958, note 92, p. 134.

101 Ipsen, note 99, p.65; Helmut Trautmann, Innere Parteiliche Demokratie im Parteienstaat [Intra-party Democracy and Party State], PhD diss., Berlin, 1975, p. 235. In rural areas, for example, it must be taken into account that members would possibly have to travel longer distances to participate in party events (Ipsen, note 99, p. 65).

102 Commission 1958, note 92, p. 134.

103 Ursula E. Heinz, Organisation innerparteilicher Willensbildung. Satzungen und innerparteiliche Demokratie [Organization of intra-party formation of the will. Statutes and inner-party democracy], PhD diss., Christian-Albrechts-University of Kiel, 1987, p. 31.

104 Rüdiger Wolfrum, Die innerparteiliche demokratische Ordnung nach dem Parteiengesetz, 1974, p. 86; Heinz, note 134, p. 26. There is a commentator in Korea, as well, Kwon (2002), who argues for a regional subdivision that goes beyond even party chapters, in order to make sure that members are able to have their say in the formation of political will (Kwon, note 82, p. 122).

105 Commission 1958, note 92, p. 157.

106 Constitutional Court of the Republic of Korea, Pulgisoch'ŏbunch'uiso, 92-hŏnma-262, 29.7.1993 [Cancellation of the disposition not to institute a public action] (1993) Hŏnbŏpchaep'anso Kyŏljŏngmun [Constitutional Court Decision Collection], Vol. 5, Nr. 2, p. 211-220, at p. 215. 
parison to other associations would originate from the fact that, first and foremost, they have the duty to participate in the formation of the political will of the people, and, second, accordingly have to have the necessary organization for being able to do so. In the Abolition Case, however, the Court deferred this interpretation to the legislature. ${ }^{107}$

Third, the territorial aspect of the above definition of functioning democratic structures makes it necessary for the organization to be substantial or real, in contrast to virtual subdivision on the Internet. The latter is not sufficient to fulfill the requirements of PartG Article 1, Sentence $1 .{ }^{108}$ This is obviously contrary to the decision of the Court, in which it ruled that local organization through media like the Internet would make up for the abolition of the party chapters. ${ }^{109}$ This becomes even more evident when one considers that the Court was obviously aware of comparable developments in other countries, ${ }^{110}$ and that there actually exist proven alternative ways of dealing with contemporary societal changes with respect to party organization other than simple abolishment.

Fourth, the Commission makes it clear that the basic structure of parties must not be restricted in their variation. Stipulations ought to leave room for different types of parties and must not show preference for a certain type. ${ }^{11}$ This is in line with the proposal by the PanCitizens' Committee for Political Reforms (PCC), ${ }^{112}$ which recommended that it should be left to individual parties to decide how to structure their inner-party organization below the level of cities and provinces. ${ }^{113}$ The Assembly, however, intentionally ignored this part of the proposal, ${ }^{114}$ and the Court — at least implicitly — reviewed the case from the biased perspective of "electoral-professional catch-all-parties."

\section{Judging by its own standard - the Party Registration Requirement Case}

In March 2004, three months before the Abolition Case had been filed by the DLP, the Socialist Party (hereafter: SP), another minor party, filed a constitutional complaint, in which it claimed

107 Court 2004, note 7, p. 629.

108 Ipsen, note 99, p. 63.

109 Court 2004, note 7, p. 627.

110 Court 2004, note 7, p. 627-628; Lee note 36, p. 783-787.

111 Commission 1958, note 92, p. 163.

112 The PCC was an entity formed in reaction to a general and potent request for political reforms that would be transparent and not confined solely to politicians in the assembly. It was comprised of various actors from politics, academia, civil society, law, and business, and filled advisory functions to the Special Sub-Committee on the Political Parties Act of the Assembly.

113 Pan-Citizens' Committee for Political Reforms (PCC), Activity Progress Report of the Pan-Citizens' Committee for Political Reforms, 2003, p. 26.

114 Sub-Committee, note 69, p. 8.

115 See Court 2004, note 96, p. 620; Jeong, note 61, p. 237 et seq. 
that Articles 25 and 27 and Articles 4 and 38 of the $P P A^{116}$, directly and indirectly "block minor or newly established parties from participating in party politics, thereby infringing upon the freedom of party formation under Article 8, Section 1, the right to equality under Article 11, and the freedom of association under Article 21, Section 1 of the Constitution." ${ }^{117}$ However, also in the Requirement Case the Court rejected the claim of unconstitutionality. ${ }^{118}$

Article 4 (Establishment) of the PPA requires political parties to register with the National Election Commission (NEC), which in turn stipulates the precondition that the party be able to meet the $P P A$ 's requirements for party establishment: that is, Article 25 (Statutory Number of City or Provincial Parties) and Article 27 (Number of Party Members of City or Provincial Parties). According to these statutes of the PPA after its amendment in 2004, political parties became obliged to have five or more party branches at the level of city or province, with one thousand or more party members in each of the branches in order to be recognized legally. In other words, parties now had to have branches in at least five regional sub-divisions, and, at a minimum, more than five thousand party members in total, which is about seven times more than before the reform (see illustration below). ${ }^{119}$ The Court stated that the minimum of five branches and five thousand members is a proper standard for local demographic circumstances, and therefore an appropriate method of realizing the requirement of Article 8, Section 2 of the Constitution. ${ }^{120}$

116 After the amendment on 12March 2004, and before the re-amendment on 4August 2005, Articles 25 and 27 became Articles 17 and 18, respectively. Article 38 changed to 44; only Article 4 stayed the same.

117 Socialist Party (Complainant). Hŏnbŏpsowŏn [Constitutional Complaint], 2004, p. 3.

118 Constitutional Court of the Republic of Korea, "Chŏngdangbŏp che-25-cho tŭng-ŭi wihŏnsŏng-e taehan kyŏljŏng" [Judgment on unconstitutionality of article 25 etc. of the Political Parties Act] (2006) in Hŏnbǒpchaep'anso Kyŏljŏngmun [18 Constitutional Court Decision Collection] p. 402-416, at p. 416.

119 Article 38 (Revocation of Registration) states that the election commission shall revoke the registration of a party that is not able to meet these requirements (among others).

120 Court 2006, note 3, p. 415. 
Illustration: Obligatory minimum number of members $(\mathrm{y})$ required for party establishment, 1962-today $(\mathrm{x})^{121}$

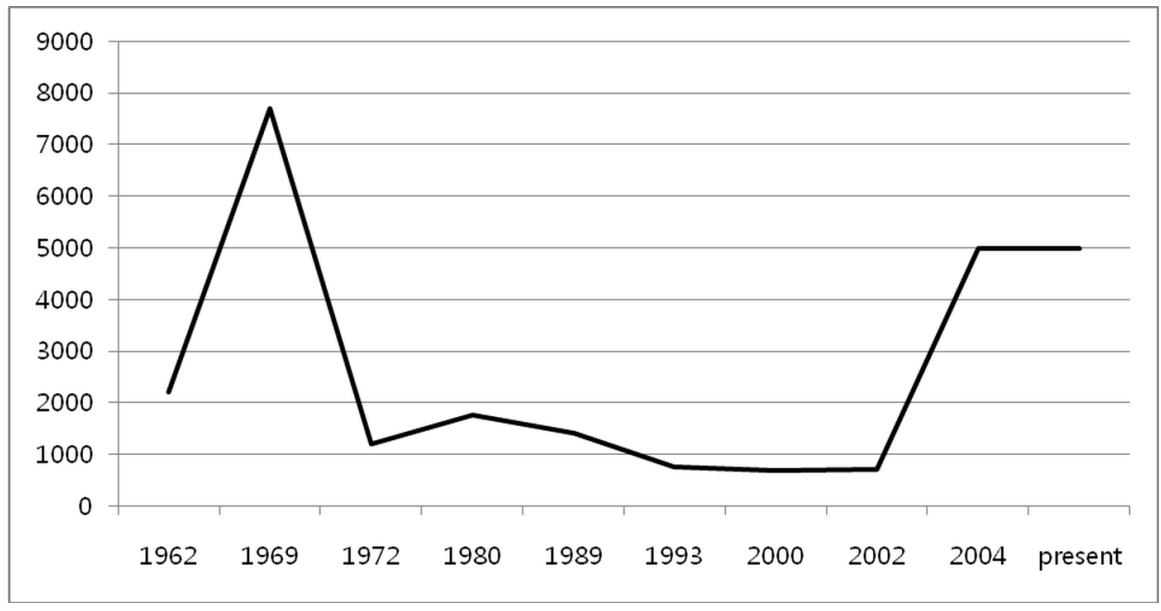

The Court by citing an earlier decision ${ }^{122}$ made clear that parties' freedom of establishment and activities is a "prerequisite of realizing democracy," explicitly pointing out the role and function of parties as "political conduits" that are "indispensable aspects of democracy" as "mediators in charge of building the political will of the citizens." 123 Its review in the Registration Case, however, followed the argumentation that the Articles in question would aim to exclude "regional parties" (Article 25) and "minor parties" (Article 27), and that this was "a legitimate legislative purpose because proper functioning of representative democracy under our Constitution requires a stable majority within the legislative branch." To exclude "regional parties, [thus] representing the political wills of only certain regions, cannot be said to be an illegitimate purpose under the Constitution, when party politics depending excessively on regional affiliation has become problematic in our political reality." 124

121 Illustration based on calculation by the author according to legally stipulated number of election districts and respective regulations in the PPA. Source: Hannes B. Mosler, "Law made in Korea (working title)," in Eun-Jeung Lee and Hannes B. Mosler (eds.), Lost and Found in Translation, Peter Lang International Publishers (forthcoming 2014).

122 Constitutional Court of the Republic of Korea, "Chŏngdangbŏp che-6-cho-ŭi wihŏnsŏng-e taehan kyŏljŏng" [Judgment on unconstitutionality of article 6 of the Political Parties Act] (2004) in Hŏnbŏpchaep'anso Kyŏljŏngmun [16 Constitutional Court Decision Collection] p. 422-440, at p. 434.

123 Court 2006, note 3, p. 411.

124 Court 2006 note 3, p. 402 et seq. It is a telling detail that during the general elections in 2004, the DLP, the smallest party in parliament, received the most evenly distributed voter support across the electorate, i.e. with the least amount of regionalism. 
Here it is important to note, that the Court's decisions on the Registration Case and on the Abolition Case are closely related (see table below): in both cases the complainant was a small, non-mainstream (i.e. minority) political party that filed the complaint after the controversial amendment of the PPA in 2004; both complaints were filed at almost the same time, and, accordingly, were reviewed almost simultaneously by the Court with no fewer than five out of seven Judges being identical in both cases; in both cases the main constitutional provision in question was Article 8, Sections 1 and 2; drawing on an earlier decision ${ }^{125}$ they share the same view on the interpretation of the "freedom of establishing a party," which would also include the "freedom to choose the form of the organization" "26. the Court rejected the complaints - unanimously in both cases.

Table: Comparing Party Registration Requirement Case and Party Chapter Abolition Case

\begin{tabular}{|c|c|c|}
\hline Item & Party Registration Requirement Case & Party Chapter Abolition Case \\
\hline complainant & Socialist Party (SP) & Democratic Labor Party (DLP) \\
\hline provision in question & $P P A$, Article $25 \& 27$ & $P P A$, Article 3 \\
\hline complaint filing & Mar. 26, 2004 & Jun. 3, 2004 \\
\hline begin of review & Apr. 13, 2004 & Jun. 15,2004 \\
\hline receiving of opinions & May 24, 2004 - Nov. 21, 2005 & Jun. 21 - Dec. 14, 2004 \\
\hline decision (constitutionality) & Mar. 30, 2006 (unanimous) & Dec. 16, 2004 (unanimous) \\
\hline provision of reference & Constitution, Article 8, Section $1 \& 2$ & Constitution, Article 8 , Section $1 \& 2$ \\
\hline \multirow{9}{*}{ judges } & Yu, Yǒng-Ch'ǒl (chief judge) & Yu, Yǒng-Ch'ǒl (chief judge) \\
\hline & Kwǒn, Sǒng & Kwǒn, Sǒng \\
\hline & Kim, Hyo-Chong & Kim, Hyo-Chong \\
\hline & Kim, Kyǒng-Il & Kim, Kyǒng-Il \\
\hline & Song, In-Chun & Song, In-Chun \\
\hline & Chu, Sǒn-Hǔi (chief referee) & Chu, Sǒn-Hǔi \\
\hline & Chǒn, Hyo-Suk & Chǒn, Hyo-Suk \\
\hline & Yi, Kong-Hyǒn & Kim, Yŏng-Il (chief referee) \\
\hline & Cho, Dae-Hyǒn & Yi, Sang-Gyǒng \\
\hline
\end{tabular}

Despite the cases' similarity there are major discrepancies of the two decisions of the Court. First, compared to the argumentation of the Abolition Case, the reasoning in the Registration Case seems to have been turned on its head. While the argument for the decision in the former case was to $c u t$ costs by reducing the depth of regional organizations (i.e. forbidding party chapters), the result of the latter was to impose costs on minor parties by dictating regional organization on a far larger scale for city/province party branches. However, a quick look at 
the development of minimum requirements with respect to numbers of members in the history of the PPA (see illustration above) makes it doubtful that the figure of 5000 members would have guaranteed intra-party democracy. ${ }^{127}$ Indeed, it is remarkably disproportional, even in comparison to respective minimum requirements during the authoritarian 1960s. Even more importantly, now that party activities are allowed only at the municipal and provincial levels and each of these organizations is obliged to have at least 5000 members in total, opportunities for individual members to participate have been reduced tremendously, since, at least arithmetically, individual members now have to deal with seven times more competitors when seeking to make their voices heard in the same time and space.

Also, in order to underline its assertion that enforcing minimum membership would be an "appropriate measure," the Court in the Registration Case presented a thorough listing of amendments to the organization-related provisions of the $P P A$ in historical perspective from 1962 onwards ${ }^{128}$ to show how the provision of "necessary organization" had been implemented until that time. ${ }^{129}$ The Court, however, failed to account for the fact that the minimum necessary membership levels had declined steadily after democratization in the 1980s, and especially after the amendment in 1993. And it completely passed over the abolition of party chapters, probable or possible ramifications of that abolition, and its own review on the Abolition Case. So, the Registration Case did not address the abolition of party chapters and its implications in any way, nor did the Abolition Case consider to the central terms "continuity," "organization," or "regional extent" that were central to the opinion in the Registration Case.

Second, in the Registration Case, the Court decided that parties must be of sufficient size, strength, permanence, and regional distribution, ${ }^{130}$ but in the Abolition Case, it decided that having regional organizations beneath the level of provinces and large cities only during election campaigns and/or as virtual entities would suffice. ${ }^{131}$ In order to underpin the need to comply with the requirements of Article 8 Section 2 of the Constitution, the Court in the Registration Case, by citing respective stipulations in German law, directly and explicitly

127 For example, Chang (2002) even argues that one should think about abolishing the strict requirements for establishing political parties altogether (Young-Soo Chang, Han'guk hŏnbŏb-ŭi miraewa chŏngdang minjujuŭi-ŭi ŭimi" [The future of Korea's constitution and the meaning of party democracy] (2002) Kongbǒbyŏn'gu [30 Public Law Research] 1-24, at p. 16). On a related note, The Court failed even to mention party members as a potential check to party leaders. In other words, this inner-party democracy mechanism is not taken into account.

128 Court 2006, note 3, p. 414 et seq.

129 Court 2006, note 3, p. 414-415.

130 Court 2006, note 3, p. 413.

131 Court 2006, note 3, p. 630. 
drew on the German Political Parties Act, ${ }^{132}$ which states that parties must have organizations that exist "permanently or for a lengthy period of time," that are of "sufficient size and strength" and that exist "considerably in the regions." 133 This is the same interpretation seen in the German Commission's report, which also conforms to the opinions of many Korean legal scholars, who invoke this interpretation in order to criticize the Court's reasoning in the Abolition Case. Here it is important to note, referring to German law in the Abolition Case as well would have been very natural, since Korean courts do this frequently, and especially because in this case German law would have been of utmost interest in terms of its existence as authoritative reference and the fifth canon for interpretations of constitutional stipulations. In any event, with the Registration Case we have an interpretation of the same Article 8 that contradicts the Abolition Case, in which the Court approves of temporary party organizations, liaison offices only at the city and province level, and the use of the Internet as a virtual organizational prosthesis.

Third, the Court's perspective on the tasks of the legislature reveals another contradiction. The Court states that "the legislature must comprehensively consider our national history of party politics, the current conditions and regional uniqueness of party politics, people's value systems and senses of justice, and the spill-over effects of the regulation, and thereby concretize the terms of continuity, organization, and regional extent."134 This does not, in itself, offer any convincing reason why the number 5000 is a proper standard. One look at the original proposals before they were submitted to the parliamentary sub-committee or at the records of the sub-committee meeting suffices to show that there was no convincing explanation for insisting on that particular number. ${ }^{135}$ More importantly, in this vein, how could the lawmakers and the constitutional judges in the Abolition Case conclude that, considering the Korean reality they emphasized, party chapters had to be abolished? A far more obvious conclusion, especially if one does consider the Korean context, would have been to reason that — independent from any specific party model - (a) the source of corruption and malpractice does not lie in the material existence of local offices but in certain political customs, ${ }^{136}$ and that subsequently (b) a reasoned solution would not be the prohibition of running offices, but rather

132 PartG, Article 2, Section 1. It is an interesting fact that it was the Ministry of Justice that cited this passage from German law in its opinion submitted to the Court (Ministry of Justice of the Republic of Korea Ministry, 2004-hŏnma-246-e taehan ŭigyŏn, chŏngdangbŏp che-25-cho-ŭi wihŏnsŏng-e taehan p'an'gyŏl [Opinion on 2004-hŏnma-246, judgment of unconstitutionality of article 25 of the Political Parties Act], 18 November 2005, p. 6), the Court, however, qualified this definition by stating that it is up to the lawmakers' judgment to decide how to substantiate these provisions within the Korean context (Court 2006, note 3, p. 413).

133 Court 2006, note 3, p. 413.

134 Court 2006, note 3, p. 413.

135 Sub-Committee 2004, note 69, p. 8.

136 Pak Hŭi-T'ae, now former president of the National Assembly, in a recent press conference informing the public of his resignation due to allegations of bribery, explicitly named the practice of distributing envelopes of money in return for votes as one of the "old customs" of Korean politics (Donga Ilbo, 20 February 2012, p.1). 
to induce different behavior - for example, by restructuring power relations and strengthening laws against corruption.

In summary, the Court based its Registration Case on legal interpretations that would have posed severe challenges to the interpretation of the Constitution in the Abolition Case, which was conducted at the same time. Most importantly, while these two constitutional reviews contradict each other in their interpretation regarding party organization, they simultaneously both decline to challenge the (logic inherent in the) newly revised PPA.

\section{E. Conclusion}

Based on the concept of judicialization of politics this article investigated the Court's decision in the Abolition Case in regard to its rationality in argumentation and methodological soundness. The analysis revealed that the Court's review was contrary to the majority of domestic legal scholarship and the interpretation of related norms in Germany; the Court's line of reasoning also showed to be in conflict with the rationale of the closely related Registration Case as well as with the reality of party operation. The most notable weakness of the review's line of argumentation was when applying the principle of proportionality (Verhältnismäßigkeitsprinzip) to rule out the possibility of any milder means other than abolition. The most striking methodological shortcoming was to explicitly stating not to judge possible consequences of the law reform, while implicitly drawing on criteria mostly identical with the features of the electoral-professional party model for evaluating the law's appropriateness. Here the Court's position and, thus, assessment criteria on the case corresponded, by and large, to the argumentation of the abolition frame that had been advocated by the major parties in the Assembly beforehand. Hence, the Court did not check against the hegemonic discourse of the time predetermined by the majority of the legislature, but aligned with it. More importantly, this contestable way of reviewing the case relates negatively to central functions of the Court - to protect rights of minorities and to prevent inappropriate partisan self-entrenchment. 